\title{
Metal bioaccumulation in edible target tissues of mullet (Mugil liza) from a tropical bay in Southeastern Brazil
}

\author{
Rachel Ann Hauser-Davis ${ }^{\mathrm{a}, *}$, Isabella C.A.C. Bordon ${ }^{\mathrm{b}}$, Terezinha F. Oliveira ${ }^{\mathrm{c}}$, \\ Roberta Lourenço Ziolli ${ }^{c}$ \\ a Universidade Federal do Estado do Rio de Janeiro (UNIRIO), de Pós-Graduação em Ciências Biológicas - Biodiversidade Neotropical, Av. Pasteur, 458, Urca, \\ CEP: 22290-240, Rio de Janeiro - RJ, Brazil \\ ${ }^{\mathrm{b}}$ Universidade Estadual Paulista (UNESP), Campus do Litoral Paulista -Praça Infante Dom Henrique s/n' ${ }^{\circ}$ Parque Bitaru, CEP: $11330-900$ - São Vicente, SP, \\ Brazil \\ ' Universidade Federal do Pará (UFPA) Instituto de Ciências Exatas e Naturais. Faculdade de Estatística and Faculdade de Ciências da Computação, Rua \\ Augusto Correa, 01, CEP: 66075-110, Belém, PA, Brazil
}

\section{A R T I C L E I N F O}

\section{Article history:}

Received 10 February 2016

Received in revised form 18 March 2016

Accepted 29 March 2016

\section{Keywords:}

Metals

Human risk assessment

Mullet

Southeastern Brazil

Tropical bay

Environmental monitoring

\begin{abstract}
A B S T R A C T
The present study aimed to investigate metal bioaccumulation in mullet (M. liza) from a tropical bay located in Southeastern Brazil, comparing a previously considered reference site to a known contaminated area of the bay, as well as to conduct human health risk assessments with regard to the consumption of this species. The metal concentrations were compared to the maximum residue level (MRL) in foods established by the different national and international regulatory agencies, and the Provisional Tolerable Daily Intake (PTDI) was determined and compared to reference values. Chromium (Cr), Zinc (Zn), Copper $(\mathrm{Cu})$, Manganese (Mn), Nickel (Ni), Cadmium (Cd) and Lead (Pb) concentrations were determined in the gills, muscle and liver of 28 mullet by ICP-MS after acid digestion. Certain metals exceeded MRL guidelines established by different regulatory agencies, indicating human health risks associated to these metals. PTDI values, however, did not exceed corresponding metal values proposed by the World Health Organization. The metal concentrations found in the mullet samples indicate that the previously considered reference site is now showing signs of anthropogenic contamination.
\end{abstract}

(c) 2016 Elsevier GmbH. All rights reserved.

\section{Introduction}

Increased attention has been given to the study of metal and trace-element content in fish in recent years, since fish ingestion as a protein source is high, with global fish contribution ranging from 10 to $15 \%$ of total human consumption [1]. These organisms are commonly situated at the top of the food chain, thereby being capable of accumulating high amounts of certain metals and trace elements, and are also highly affected by aquatic environmental pollution, leading to potential health risks for human consumers [2]. It has been recognized that the determination of metal levels in fish muscle is extremely important with regard to human health due to this being the main edible tissue, although muscle is not an active tissue in accumulating metals and does so only when detoxification attempts by other routes are not entirely successful, resulting in metal bioaccumulation [3].

\footnotetext{
* Corresponding author.

E-mail address: rachel.hauser.davis@gmail.com (R.A. Hauser-Davis).
}

Mullet are routinely consumed by humans worldwide, and are among the most common species in tropical and temperate marine coastal waters. They are also a recognized sentinel species regarding metal contamination, since they are limnobenthofagous, and, therefore, particularly exposed to sediment-associated contamination, such as metals [4]. In Brazil, mullet is heavily consumed around coastal areas, and is the most produced species in the Rio de Janeiro state [5]. In fact, in several areas of this state, not only is mullet fillet highly consumed, but mullet liver is considered a delicacy. This can exacerbate potential health risks to human consumers, since some metals accumulate primarily in this organ.

One of the most important estuaries in the Rio de Janeiro state and, in fact, of the Brazilian coast, is the Guanabara Bay. It has a total area of approximately $400 \mathrm{~km}^{2}$ and approximately 11 million inhabitants live in the surrounding regions. Certain areas of the bay receive environmental impacts on a daily basis, such as domestic sewage and non-treated industrial effluents from the 12,000 industries, oil refineries, two navy bases and shipyards around the bay. Due to the latter, anticorrosive and primer paints used in ships are an important source of $\mathrm{Zn}$ to this environment [6]. Because 
of this, certain areas of the bay suffer heavily from the effects of organic matter, oils, organic compounds and metals [7]. However, even with these environmental impacts, some areas of the bay have been considered non-contaminated reference areas, and the entire bay is still a significant fishing site of social and economic importance, retaining about $90 \mathrm{~km}^{2}$ of fringing mangroves which aids in maintaining local biota diversity [8].

One of the bay areas historically considered a reference area, with no episodes of contamination such as oil spills or sewage dumping, for example, is Itaipu beach. This area is nearer open waters, not as exposed to contamination as the inner areas of the bay since a gradient of decreasing pollution toward the Atlantic Ocean is present [9]. The fishery production at this site is locally significant, supplying the majority of fresh fish products to the nearby surrounding areas and local populations. The estimated total annual production for this area alone represents approximately $0.7 \%$ of the Guanabara Bay fisheries production and was responsible for $0.2 \%$ of the total production in Rio de Janeiro in 2004 [5]. Recent studies, however, have indicated that this area is slowly showing signs of anthropogenic contamination, since metal concentrations in certain biota, such as filter-feeding mussels, presented metal concentrations above the maximum permissible levels for human consumption dictated by the Brazilian legislation [10], as well as worrisome metal levels in fish bile, indicating metal exposure and attempts at metal detoxification from the body [11].

Therefore, in this context, the present study aimed to investigate and compare metal bioaccumulation in mullet muscle and liver from the previously considered reference site of Itaipu beach and a heavily contaminated area of the Guanabara Bay, Ipiranga Beach. Gills were also included since this matrix is in direct contact with water and ressuspended sediment particles and may further indicate the presence of waterborne metals [3]. In addition, the results were compared to maximum permissible levels established by different Brazilian and international regulatory agencies, and estimated daily ingestion values were determined for metal intake through mullet liver and muscle consumption, which were, in turn, compared with reference values proposed by regulatory agencies.

\section{Material and methods}

\subsection{Sampling sites}

Fish were sampled in the summer of 2009/2010 (November 2009 in Ipiranga and February 2010 at Itaipu) from two different locations within the Guanabara Bay: Itaipu beach (nearer open waters, routinely used as a reference site for environmental monitoring studies, $n=14$ ) and Ipiranga beach (closer to the back of the bay, where there are weaker water currents, near several industrial activities including industries, oil refineries, navy bases, shipyards and two huge oil pipelines, historically known as a highly contaminated area, $\mathrm{n}=14$ ) (Fig. 1, modified from Ref. [12]).

\subsection{Sample processing}

Fish were euthanized by spinal cord severing and put on ice until arrival at the laboratory, to minimize tissue decay and maintain a moist environment during transport. At the laboratory the fish were sexed when possible, measured and weighed. Liver, gills and muscle tissue were excised, aliquoted and immediately frozen at $-80^{\circ} \mathrm{C}$ and stored in sterile polypropylene tubes until analysis. Samples were prepared by allowing the frozen tissues to thaw at room temperature; approximately $1.0 \mathrm{~g}$ of each tissue was immediately transferred to a $50 \mathrm{~mL}$ screw-capped conically ended polypropylene tube, $3.0 \mathrm{~mL}$ of concentrated $\mathrm{HNO}_{3}$ (Vetec, São Paulo, Brazil) were added and the mixture was left overnight at room temper-
Table 1

Instrumental limit of detection (LOD) and limit of quantification (LOQ) for the metals determined in the present study $\left(\mu \mathrm{gg}^{-1}\right)$.

\begin{tabular}{llllllll}
\hline & $\mathrm{Cr}$ & $\mathrm{Mn}$ & $\mathrm{Ni}$ & $\mathrm{Cu}$ & $\mathrm{Cd}$ & $\mathrm{Pb}$ & $\mathrm{Zn}$ \\
\hline LOD & 0.24 & 0.03 & 0.03 & 0.12 & 0.01 & 0.25 & 0.47 \\
LOQ & 0.80 & 0.11 & 0.11 & 0.41 & 0.04 & 0.82 & 1.56 \\
\hline
\end{tabular}

Table 2

Biometric data regarding the sampled fish from Itaipu $(n=14)$ and Ipiranga $(n=14)$. Data is displayed as means $\pm \mathrm{SD}$.

\begin{tabular}{lll}
\hline Sampling site & Itaipu & Ipiranga \\
\hline Weight $(\mathrm{g})$ & $825.72 \pm 274.59$ & $828.84 \pm 232.35$ \\
(min-max) & $(373.29-1284.5)$ & $(533.75-1274.5)$ \\
Length $(\mathrm{cm})$ & $45.61 \pm 5.73$ & $46.50 \pm 4.13$ \\
(min-max) & $(34.00-54.00)$ & $(41.2-53.6)$ \\
\hline
\end{tabular}

ature. Digestions were completed by placing the tubes in a water bath at $90-100{ }^{\circ} \mathrm{C}$ for approximately $2 \mathrm{~h}$. After cooling, $1 \mathrm{~mL}$ of $\mathrm{H}_{2} \mathrm{O}_{2}$ (Merck, Darmstadt, Germany) was added and the samples were then placed in the water bath for another $2 \mathrm{~h}$. The samples were then diluted appropriately for ICP-MS determinations with ultrapure water (resistivity $>18.0 \mathrm{M} \Omega \mathrm{cm}$ ).

\subsection{ICP-MS determinations}

Chromium ( $\mathrm{Cr})$, manganese $(\mathrm{Mn})$, zinc $(\mathrm{Zn})$, lead $(\mathrm{Pb})$, nickel $(\mathrm{Ni})$, copper $(\mathrm{Cu})$ and cadmium $(\mathrm{Cd})$ concentrations were determined, on an Agilent ICP-MS (Model 7500X, Tokyo, Japan) in triplicate, using external calibration with multielemental calibration solutions obtained by appropriate dilutions of a mixed standard solution (Merck IV). To compensate for matrix interferences ytterbium $(\mathrm{Y})$ was used as internal standard and calibration solutions were prepared in the blank medium. The accuracy of the analytical procedure was verified with procedural blanks and by the parallel analysis of certified reference materials (DORM-2, dogfish muscle tissue, and DOLT-3, dogfish liver; National Research Council of Canada), in triplicate. The recovery results of the certified reference materials were satisfactory, ranging from $83 \%$ to $131 \%$, according to EPA criteria (EPA, 2000). The instrument limit of detection (LOD) and limit of quantification (LOQ) were estimated as 3 SD of ten blank measurements and 10 SD the of 10 blank measurements, respectively, where SD is the standard deviation for the blank measurements (Table 1 ).

\subsection{Statistical analyses}

Data normality was tested using the Shapiro-WilkW test prior to additional statistical analyses. Differences were considered significant when $\mathrm{p}<0.01$. Student's t-test was applied to verify differences between parameters between the sampling sites since the number of samples was the same for each location. The statistical analyses were performed on the Statistica 10 (StatSoft) software package for Windows.

\section{Results and discussion}

\subsection{Biometric data}

The biometric data of weight $(\mathrm{g})$, length $(\mathrm{cm})$ and range for each of these parameters regarding the sampled fish from Itaipu and Ipiranga are displayed in Table 2 . Data is shown as means \pm SD. Fish from both locations were similar in size, with no statistically significant differences in length and weight parameters (Student's t-test, $\mathrm{p}<0.01$ ). All sampled fish were adults, showing active gonadal maturation, with both spawning and post-spawning individuals. 


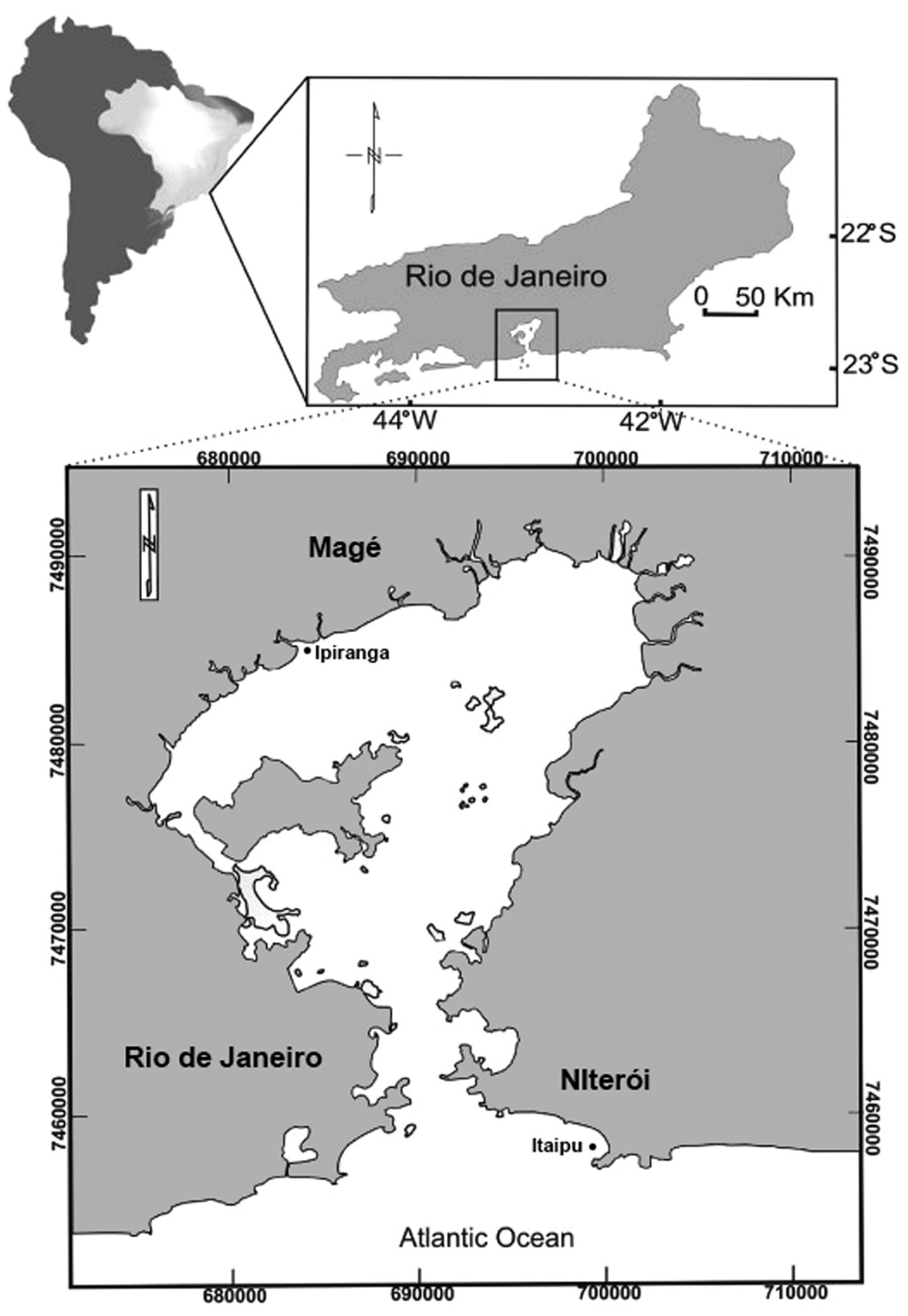

Fig. 1. Map indicating the mullet sampling areas located in Guanabara Bay, Southeastern Brazil. 


\subsection{Metal concentrations in mullet gills, liver and muscle tissue}

All $\mathrm{Cr}$ and $\mathrm{Pb}$ concentrations were below the LOQ. As the Shapiro Wilk test did not detect data normality, data is displayed as medians and ranges determined as wet weight (w.w.) (Table 3). In liver, $\mathrm{Zn}$ was higher at Ipiranga, while Mn and Cd were higher at Itaipu. In gills, Mn was higher at Ipiranga. Cd was not detected in quantificable amounts in the majority of the gill samples, while $\mathrm{Ni}, \mathrm{Cu}$ and Zn were higher at Itaipu.

Due to differential metal absorption, regulation, storage and excretion, different tissues show different bioaccumulation rates [13]. Muscle tissue is not always a good indicator of contamination, since many other detoxification processes might be active, such as metallothionein metal sequestering and liver storage. It is important to note that, in the case of mullet in Southeastern Brazil, liver is routinely ingested by the human population, many times whole, which can increase the likelihood of metal contamination by this route in humans. Thus, it is important to analyze other organs such as liver and gills to indicate metal exposure.

Three of the elements determined in this study ( $\mathrm{Cu}, \mathrm{Zn}$ and $\mathrm{Mn}$ ) are essential but show toxic effects when organisms are exposed to levels higher than normally required [14]. $\mathrm{Cu}$ and $\mathrm{Zn}$ are cofactors in a number of enzymes and metalloproteins for most living organisms, but in toxic levels $\mathrm{Cu}$ targets primarily the gills, leading to impairment of the respiratory and ion regulatory functions [15], while $\mathrm{Zn}$ reduces the liver capacity in high concentrations, and may be transported through the bloodstream to other organs [16]. Finally, Mn is of moderate toxicity to aquatic organisms and its uptake in fish has been reported to be mainly through gills [17]. The other elements determined in this study ( $\mathrm{Ni}$ and $\mathrm{Cd}$ ), on the other hand, do not play any essential role in metabolic activities and exhibit toxic properties. Ni is a known carcinogenic and mutagenic element and fish show sub-lethal effects when exposed to high Ni levels [17]. Cd can cause cellular injury and alterations in the activities of several enzymes in fish and shows high potential for bioconcentration and accumulation in these organisms [18].

In the present study, metal concentrations in muscle tissue of the fish sampled from both sites were lower than those in other tissues, except for $\mathrm{Mn}$ in gills at Itaipu. The following trend was in general observed at both sites: $\mathrm{Mn}, \mathrm{Zn}$ and $\mathrm{Cd}$ concentrations were higher in liver and $\mathrm{Ni}$ concentration was higher in gills. In general, the concentrations observed in liver samples from Itaipu were higher than the concentrations observed in tissues of organisms collected at Ipiranga. These results seem to indicate efficient detoxification by the liver and lesser bioaccumulation in muscle for most of the investigated metals at both sites. In fish, gills represent the largest surface in contact with the aquatic environment and are, thus, expected to show the greatest tissue alteration and metal accumulation [19]. In the case of $\mathrm{Ni}$ and $\mathrm{Cu}$, were higher in gills from Itaipu even when compared to liver at Ipiranga, which seems to corroborate increased metal adsorption on the gill surface from higher metal levels in the water at Itaipu, as reported previously [20].

\subsection{Comparison of trace element concentrations in mullet} muscles and liver with international standards for potential health risks

Besides the potential effects on the health of the fish themselves, the studied trace-elements show potential toxic effects in humans when ingested over certain permissible limits. As muscle tissue is the main edible fish part and can directly influence human health it is of paramount importance to investigate in further detail the metal content in this tissue, relating them to guidelines regarding heavy metals and their maximum permissible concentrations. However, as noted previously, the Brazilian population has the particularity of ingesting mullet liver in several typical recipes, sometimes whole, which may pose higher health risks than muscle ingestion, since liver usually presents much higher metal concentrations than muscle. Thus, in order to evaluate human exposure to the investigated metals through the consumption of mullet muscle and liver in southeastern Rio de Janeiro, results, expressed in wet weight were compared to the maximum residue level (MRL) in foods established by the Brazilian (ANVISA) [21], the Food and Agriculture Organization of the United Nations (FAO) [22], the American Food and Drug Administration and the Environmental Protection Agency (US FDA and US EPA) [23,24], the British Ministry of Forestry, Agriculture and Fisheries [25] and the European Community (EC) legislation [26] (Table 4).

The percentage of samples that exceeded the MRLs for the different guidelines are displayed in Table 5. Results were assessed according to the most restrictive guideline, since this is the usual method in these types of studies, and worldwide guidelines state that the values determined in the guidelines are already cause for health concerns. Muscle $\mathrm{Mn}(86 \%, 12 / 14)$ and $\mathrm{Cu}(7 \%, 1 / 14)$ values exceeded MRL guidelines at Itaipu, while samples from Ipiranga showed only $\mathrm{Cu}(7 \%, 1 / 14)$ above maximum permissible levels. Regarding liver, which is, as stated previously, considered a delicacy throughout the state of Rio de Janeiro, $\mathrm{Mn}, \mathrm{Cu}, \mathrm{Cd}$ and $\mathrm{Zn}$ all exceeded guidelines, from both locations, at varying degrees (with $\mathrm{Zn}$ always exceeding guidelines in $100 \%$ of the samples, and $\mathrm{Mn}$ in $93-100 \%$ of the samples). This organ, however, is not as consumed as muscle, so these metals are probably not of concern regarding liver ingestion.

The results of the present study, therefore, corroborate several studies indicating that Ipiranga is heavily contaminated by metals. In addition, they also corroborate recent, and still scarce, literature, that indicates that Itaipu beach is slowly losing its status as a reference site and can now be classified as polluted, with metals being very bioavaliable to the local biota due to the advent of intensive naval activities, and the presence of the harbour and dockyards located in the area, which have been recently reported as potential sources and sinks for accumulation of heavy metals and, thus, contaminated sediments [27].

It is important to note that there is a great range of values accepted for each metal, with some regulatory agencies indicating much lower values as worrisome for human health, resulting in $\mathrm{Mn}, \mathrm{Cu}, \mathrm{Cd}$ and $\mathrm{Zn}$ in liver from both sites, $\mathrm{Cu}$ in muscle from both sites, and $\mathrm{Mn}$ in muscle from Itaipu not being safe for human consumption. As previous studies have noted, in order to enable a more efficient control of contaminants in fish products, there is an urgent need to resolve the problem of lack of legal limits for many metals, both in Brazilian and international legislations [28].

Knowledge regarding the daily ingested dose of a specific element allows for estimations on the maximum amount of food that can be consumed safely without risks of deleterious effects, known as the Provisional Tolerable Daily Intake (PTDI), which has been established by several countries and/or regulating agencies, such as the Joint FAO/WHO Expert Committee on Food Additives (JECFA) [29]. In this context, the estimated dietary intakes of metals were determined for mullet muscle and liver from both sampling sites and compared to the reference value proposed by the WHO for both muscle and liver. Brazil has an average intake of $24.74 \mathrm{~g}$ daily of fish per capita, or an average of $173.18 \mathrm{~g}$ per week. In the metropolitan Rio de Janeiro area, however, this intake doubles, to $355.00 \mathrm{~g}$ per week, the equivalent of $50.71 \mathrm{~g}$ per day [30]. Thus, the highest metal value from each sampling site and matrix was multiplied by the average fish consumption in the metropolitan Rio de Janeiro area and divided by the mean body weight of a Brazilian adult (estimated at $70 \mathrm{~kg}$ ). In the present study, the estimated daily dietary intake values of trace elements in mullet muscle were not above the limits imposed by WHO. The same occurred for liver, how- 
Table 3

Medians and ranges for metal concentrations ( $\mu \mathrm{g} \mathrm{g}^{-1}$ w.w.) determined in mullet gills, muscle and liver from Itaipu and Ipiranga Beach.

\begin{tabular}{|c|c|c|c|c|c|}
\hline & \multicolumn{5}{|l|}{ Itaipu } \\
\hline & Mn & $\mathrm{Ni}$ & $\mathrm{Cu}$ & $\mathrm{Cd}$ & $\mathrm{Zn}$ \\
\hline Gills & $0.16(<\mathrm{LOQ}-0.50)$ & $0.43(<\mathrm{LOQ}-0.87)$ & $0.94(<$ LOQ -6.12$)$ & $<\mathrm{LOQ}(<\mathrm{LOQ}-0.09)$ & $11.27(<\mathrm{LOQ}-14.28)$ \\
\hline Muscle & $1.18(<\mathrm{LOQ}-3.68)$ & $<\mathrm{LOQ}(<\mathrm{LOQ}-0.32)$ & $<\mathrm{LOQ}(<\mathrm{LOQ}-2.40)$ & $<\mathrm{LOQ}(<\mathrm{LOQ}-0.05)$ & $3.57(<\mathrm{LOQ}-4.20)$ \\
\hline \multirow[t]{3}{*}{ Liver } & $2.43(0.13-3.52)$ & $0.13(<\mathrm{LOQ}-0.57)$ & $0.81(<\mathrm{LOQ}-4.33)$ & $0.13(0.07-0.50)$ & $64.61(26.75-85.15)$ \\
\hline & Ipiranga & & & & \\
\hline & Mn & $\mathrm{Ni}$ & $\mathrm{Cu}$ & $\mathrm{Cd}$ & $\mathrm{Zn}$ \\
\hline Gills & $0.36(0.17-0.56)$ & $0.16(<\mathrm{LOQ}-0.62)$ & $<$ LOQ (<LOQ-0.63) & $<\mathrm{LOQ}(<\mathrm{LOQ}-0.04)$ & $2.23 \quad(1.71-3.17)$ \\
\hline Muscle & $<$ LOQ & $<\mathrm{LOQ}$ & $<\mathrm{LOQ}(<\mathrm{LOQ}-15.57)$ & $<\mathrm{LOQ}(<\mathrm{LOQ}-0.04)$ & $<\mathrm{LOQ}$ \\
\hline Liver & $0.59(0.47-0.83)$ & $<\mathrm{LOQ}$ & $<$ LOQ $(<$ LOQ -1.40$)$ & $0.06(0.05-0.07)$ & $74.31(53.83-111.58)$ \\
\hline
\end{tabular}

Table 4

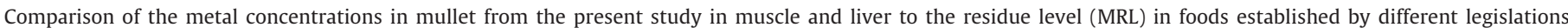
( $\mu \mathrm{gg}^{-1}$ w.w.).

\begin{tabular}{|c|c|c|c|c|c|c|}
\hline & Matrix & Mn & $\mathrm{Ni}$ & $\mathrm{Cu}$ & $\mathrm{Cd}$ & $\mathrm{Zn}$ \\
\hline \multirow[t]{2}{*}{ Itaipu } & Muscle & $<$ LOQ-3.68 & $<$ LOQ-0.32 & <LOQ 2.40 & $<$ LOQ -0.05 & $<\mathrm{LOQ}-4.20$ \\
\hline & Liver & $0.13-3.52$ & $<\mathrm{LOQ}-0.57$ & $<\mathrm{LOQ}-4.33$ & $0.07-0.50$ & $26.75-85.15$ \\
\hline \multirow[t]{2}{*}{ Ipiranga } & Muscle & $<\mathrm{LOQ}$ & $<$ LOQ & $<$ LOQ -15.57 & $<$ LOQ -0.04 & $<\mathrm{LOQ}$ \\
\hline & Liver & $0.47-0.83$ & $<$ LOQ & $<\mathrm{LOQ}-1.40$ & $0.05-0.07$ & $53.83-111.58$ \\
\hline ANVISA & & - & 5 & 30 & 2 & 50 \\
\hline MAFF & & - & - & 20 & 0.2 & 50 \\
\hline FAO & & 0.5 & - & 30 & 1 & 30 \\
\hline EPA & & - & - & $1.0-20.0$ & $>2.0$ & $10.00-30.00$ \\
\hline US FDA & & - & 80 & $\mathrm{x}$ & 3.7 & $\mathrm{x}$ \\
\hline $\mathrm{EC}$ & & - & - & $\mathrm{x}$ & 0.05 & $\mathrm{x}$ \\
\hline
\end{tabular}

Table 5

Percentage of samples that exceeded the permissible levels by different Brazilian and international guidelines.

\begin{tabular}{|c|c|c|c|c|c|c|}
\hline Sampling site & Matrix & Mn & $\mathrm{Ni}$ & $\mathrm{Cu}$ & $\mathrm{Cd}$ & $\mathrm{Zn}$ \\
\hline \multirow[t]{2}{*}{ Itaipu } & Muscle & $86 \%(12 / 14)$ & $0 \%(0 / 14)$ & $7 \%(1 / 14)$ & $0 \%(0 / 14)$ & $0 \%(0 / 14)$ \\
\hline & Liver & $93 \%(13 / 14)$ & $0 \%(0 / 14)$ & $43 \%(6 / 14)$ & $100 \%(14 / 14)$ & $100 \%(14 / 14)$ \\
\hline \multirow[t]{2}{*}{ Ipiranga } & Muscle & $0 \%(0 / 14)$ & $0 \%(0 / 14)$ & $7 \%(1 / 14)$ & $0 \%(0 / 14)$ & $0 \%(0 / 14)$ \\
\hline & Liver & $100 \%(14 / 14)$ & $0 \%(0 / 14)$ & $7 \%(1 / 14)$ & $71 \%(10 / 14)$ & $100 \%(14 / 14)$ \\
\hline
\end{tabular}

ever this organ, although considered a delicacy in Brazil, is not as consumed as muscle, and, thus, the estimated dietary intakes of metals for this organ are also not of concern. However, it is important to remember that certain local populations consume much more fish per day/week than the average individual, such as the fishermen colonies located around the sampling areas, which are of considerable size. Since Rio de Janeiro's production already surpasses 1000 ton $\mathrm{yr}^{-1}$ for mullet, mainly from artisanal catches [5], making this species one of the most consumed in the coastal areas of Rio de Janeiro, health concerns with regard to the ingestion of mullet muscle at the metropolitan Rio de Janeiro area are possible.

\section{Conclusions}

Mullet muscle and liver (which is ingested by the local Rio de Janeiro population regularly) from both study areas of the Guanabara Bay showed concentrations above Brazilian and International guidelines for MRL in food, which can pose a health risk but, considering the amount of the consumed fish, the metal amounts ingested by humans are still not in the range that could cause health problems. Itaipu can now, unfortunately, also be classified as metalcontaminated beach, probably due to the intense naval activities occurring in this area for the last years. Due to mullet popularity in the Rio de Janeiro area, coupled to the fact that the local population still considers Itaipu a reference site, further environmental monitoring studies regarding metal concentrations should be conducted in these areas, both in the biota and in the water.

\section{Conflict of interest}

The authors declare no conflicts of interest with regard to this work.

\section{Acknowledgments}

R.A. Hauser-Davis would like to thank the Brazilian National Counsel of Technological and Scientific Development - CNPq - for her doctorate scholarship. Special thanks go to Gabriella Marques de Campos and Raquel Lavradas for their technical support in the ICP-MS analyses and fish dissections, respectively.

Special thanks go to Prof. Reinaldo Calixto (in memoriam), for his invaluable help during this work.

\section{References}

[1] R.P. Wilson, G. Corraze, Foreword-Nutrition and feeding of fish 267 (2007) $1-2$.

[2] A.L.J. Peter, T. Viraraghava, Thallium: a review of public health and environmental concerns, Environ. Int. 31 (2005) 493-501.

[3] P. Zhuang, Z. Li, M.B. McBride, B. Zou, G. Wang, Health risk assessment for consumption of fish originating from ponds near Dabaoshan mine South China, Environ. Sci. Pollut. Res. 20 (2013) 5844-5854.

[4] S.L. Shah, A. Attinag, Effects of heavy metals accumulation on the 96-h Lc50 values in Tench (Tinca tinca L.) 1758, 29 (2005) 139-144.

[5] IBAMA, Estatística da pesca 108 (2005).

[6] J.A. Baptista-Neto, M. Crapez, J.J. Mcalister, C.G. Vilela, Concentration and bioavailability of heavy metals in sediments from Niteroíi Harbour (Guanabara Bay/S.E. Brazil) 20 (2005) 0749-0208.

[7] L.A. Azevedo, I.M.R.D. Bruning, I. Moreira, Hydrocarbon contamination in mussels from Guanabara Bay, Mar. Pollut. Bull. 49 (2004) 1120-1122.

[8] S. Jablonski, A.F. Azevedo, L.H.A. Moreira, Fisheries and conflicts in Guanabara Bay, Rio de Janeiro, Brazil. 49 (2006) 79-91. 
[9] G.O. Fistarol, F.H. Coutinho, A.P.B. Moreira, T. Venas, A. Cánovas, J. Sérgio, E.M de Paula, R. Coutinho, R.L.d. Moura, J.L. Valentin, D.R. Tenenbaum, R. Paranhos, R.d.A.B.d. Valle, A.C.P. Vicente, G.M.A. Filho, R.C. Pereira, R. Kruger, C.E. Rezende, C.C. Thompson, P.S. Salomon, F.L. Thompson, Environmental and Sanitary Conditions of Guanabara Bay, Rio de Janeiro, 6 (2015).

[10] R.T. Lavradas, R.C.C. Rocha, T.D. Saint'Pierre, J.M. Godoy, R.A. Hauser-Davis. Investigation of thermostable metalloproteins in Perna perna mussels from differentially contaminated areas in Southeastern Brazil bybioanalytical techniques, 34 (2016) 70-78.

[11] R.A. Hauser-Davis, F.F. Bastos, T.F. Oliveira, R.L. Ziolli, R.C. de Campos, Fish bile as a biomarker for metal exposure, Mar. Pollut. Bull. 64 (2012) 1589-1595.

[12] C.M.A. Rangel, J.A. Baptista-Neto, E.M. Finseca, J. McAlister, B.J. Smith, Study of heavy metal concentration and partitioning in the Estrela River: implications for the pollution in Guanabara Bay - SE Brazil 83 (2011) 801-816.

[13] M.M. Storelli, G. Barone, A. Storelli, G.O. Marcotrigiano, Trace metals in tissues of Mugilids (Mugil auratus, Mugil capito and Mugil labrosus) from the Mediterranean Sea, 77 (2006) 43-50.

[14] C.M.A. Ademoroti, Environ. Chem. Toxicol. (1996) 171-204.

[15] A.G. Heath, Water Pollution and Fish Physiology, 359 (1991).

[16] S.S. Murugan, R. Karuppasamy, K. Poongodi, S. Puvaneswari, Bioaccumulation pattern of zinc in freshwater fish Channa punctatus (Bloch.) after chronic exposure, 8 (2008) 55-59.

[17] G. Nussey, J.H.J. van Vuren, H.H. du Preez, Bioaccumulation of chromium, manganese, nickel and lead in the tissues of the moggel, Labeo umbratus (Cyprinidae), from Witbank Dam, Mpumalanga, 26 (2000) 269-284.

[18] F. Yilmaz, The Comparison of Heavy Metal Concentrations ( $\mathrm{Cd}, \mathrm{Cu}, \mathrm{Mn}, \mathrm{Pb}$, and $\mathrm{Zn}$ ) in Tissues of Three Economically Important Fish (Anguilla anguilla, Mugil cephalus and Oreochromis niloticus) Inhabiting Köycegiz Lake-Mugla (Turkey), 4 (2009) 7-15.

[19] S. Yildiz, B. Gurcu, Y.B. Koca, S. Koca, Histopathological and genotoxic effects of pollution on Anguilla anguilla in the Gediz River (Turkey), J. Anim. Vet. Adv. 9 (2010) 2890-2899.
[20] M. Canli, G. Atli, The relationships between heavy metal ( $\mathrm{Cd}, \mathrm{Cr}$, Cu, Fe, Pb, Zn) levels and the size of six Mediterranean fish species, Environ. Pollut. 121 (2003) 129-136.

[21] BRAZIL. ANVISA, Agência Nacional de Vigilância Sanitária. Decreto no 55.871, 26 de março de (1965).

[22] FAO, FAO fishery circular No. 464, 5-100. Compilation of legal limits for hazardous substances in fish and fishery products. Food and Agriculture Organization of the United Nations, Rome. (1983).

[23] US-EPA. Risk based concentration Table (2007).

[24] US-FDA. Food and Drug Administration. Guidance Document for metals in Shellfish. DHHS/PHS/FDA/CFSAN/Office of Seafood, Washington, DC (1993).

[25] MAFF. Monitoring and surveillance of non-radioactive contaminants in the aquatic environment and activities regulating the disposal of wastes at sea. Directorate of Fisheries Research, Lowestoft (1995) 44.

[26] EC, Commission regulation no. 466/2001 of 8 March (2001), 1.77/1.

[27] J.A.B. Neto, M. Crapez, J.J. McAlister, C.G. Vilela, Concentration and bioavailability of heavy metals in sediments from Niterói harbour (Guanabara Bay/S.E Brazil). 21 (2005) 811-817.

[28] I. Jarić, Z. Višnjić-Jeftić, G. Cvijanović, Z. Gačić, L. Jovanović, S. Skorić, M. Lenhardt, Determination of differential heavy metal and trace element accumulation in liver, gills, intestine and muscle of sterlet (Acipenser ruthenus) from the Danube River in Serbia by ICP-OES, Microchem. J. 98 (2011) 77-81.

[29] WHO, Evaluation of certain food additives and contaminants (41st report of the Joint FAO/WHO Expert Committee on Food Additives) WHO Technical Report Series, 837, World Health Organization, Geneva, 1993.

[30] BRAZIL, Apparent Per Capital Consumption of Fish in Brazil, (2009) 1996-2009. 